\title{
MetaKosovo: Local and International Narratives
}

\author{
Vjosa Musliu and Jan Orbie
}

\author{
Research Highlights and Abstract \\ This article:
}

- Problematizes the concept of 'home' and 'hospitality' in the case of unfinished states in terms of sovereignty;

- Argues that the concept of home is always preconditioned by the differences of host and guest; in cases where these two are intermingled/confused/unclear, the concept of home changes too;

- Looks at local and international narratives on Kosovo as a struggle of conceptual ownerships;

- Asserts that international and local narratives are always already both subject and object, yet fully neither at the same time, they exist and are destroyed by their own, and their subjectivity therefore lies in their autoimmunity, which makes them intrinsically undecidable;

- States that the Serbs and the Albanians have reached a historical point on their claim on Kosovo, where they share Kosovo as a state beyond 'home' (beyond sovereignty); for the Serbs, Kosovo as their previous 'home' is beyond remedy, for the Albanians Kosovo as their new/legitimate 'home' is beyond reach.

This article examines local narratives on Kosovo and their role in crafting and articulating interpretations of Kosovo and international missions. Using the concept of 'home', as used and conceptualised by Jacques Derrida, the article reverses the order of who is 'guest' and 'host' in Kosovo and how that defines the local narratives on the subject. In the first part, attention is paid solely to letting local narratives deconstruct themselves, while in the second part we let them deconstruct the international narrative on Kosovo. The aim of the article is to present Kosovo as a battleground of division and commonality among the narratives and at the same time as an 'impossible' 'home' of all its narratives. In conclusion, some thoughts pave the way for the idea of 'renegotiating' the concept of 'home' with particular focus on 'home' in interventions and missions and its ultimate influence on the ethics of intervention.

Keywords: hospitality; Derrida; Kosovo; EU

\section{Introduction}

This article looks at the competing/different narratives on Kosovo-narratives of its local population-in relation to the international narratives on Kosovo. During the author's field work in Kosovo, it was revealed that there is something essential in the local narratives themselves that needs to be unravelled. Throughout the interview process, it became clear that something was happening at the subterranean 
level, something that not many people were paying much attention to: a dissatisfaction accumulating among the people. In the cacophony of grand projects for Kosovo-to bring it closer to 'euro-Atlantic structures'; to make it a model country of rule of law and democracy; to bring it closer to European standards and valuesthe article reverses the focus by bringing the local narrative to the centre and pushes aside, for a moment, Kosovo as a democratising project.

Since its unilateral declaration of independence in 2008, Kosovo has been recognised by more than 100 states. While Serbia maintains its staunch opposition to its independence, Kosovo's status remains contested at the international level, as it is not yet a member of the United Nations. The European Union has not recognised Kosovo's independence 'en bloc' either, and has come up with the definition of 'status neutral', leaving it up to its member states to decide on their own relations with Kosovo. This superfluid state of matter (in terms of status identification) has its implications at the local level, as groups/ethnicities claim/contest/oppose their right to claim Kosovo as their own. Broadly, at the international political level, the international intervention is seeking to 'test' the creation of the very first postWestphalian/post-modern political entity bypassing the issue of status settlement. At the local political level however, the discourse has remained anchored along the lines of 'finishing' the state-in Westphalian terms. The local people in Kosovo assert the necessity of belonging to a country/state which they own. These aspirations do not only speak to the very idea of having an independent state; yet, they are quintessentially linked to the very concept of belonging to the subject of identification and ultimately being recognised (in terms of subjectivity) in the international arena which is composed of sovereign states. Importantly, this conceptualisation talks to dimensions of ethos and justice and as such when we speak of Kosovo as a structure/state/belonging, we refer to it as 'home', which in political science jargon would be equated with 'state': Kosovo as the home of its people.

In his work titled 'Metabosnia: Narratives of the Bosnian War', Derridean scholar David Campbell focuses on narrativizing strategies of objectivist works dealing with the Bosnian War, highlighting issues of both interpretation and representation. He suggests that a concern with the narratives can be important when it comes to making judgments about competing accounts of contentious events and issues (Campbell, 1998a, 267). Evidencing the competing narratives on Kosovo as home, as belonging, from its local and international 'stakeholders', this article takes Campbell's conceptualisation of 'Metabosnia' and uses it to grasp and articulate the narratives on Kosovo, what Kosovo means for each narrative, and how each narrative claims ownership in its own story and ultimately claims ownership of Kosovo as a structure, as a state, and as a project. Thus, the main aim of this article is to look at the local and international narratives in a competing battleground, unravel their underlying meanings and dimensions and ultimately claim that for 'unfinished' societies, the concept of being host of their home-to finalise the project of statehood-remains strong, notwithstanding the trends of post-national/ post-Westphalian debates on states.

We embark by reversing binary oppositions of local narratives constructed from interviews, a literature review and the author's capability to synthesise these data. In reversing the binary oppositions with deconstruction, we align with what 
Derrida calls the marginal, or the oppressed. Because of the high degree of international intervention and presence of missions, both in their structural and conceptual form, Kosovo has many more of the characteristics of a protectorate/ semi-protectorate than those of a state. This has led to a situation in which the roles of the 'host' (the missioniser) and the 'guest' (the local) have been reversed. The missioniser has become the 'host' in that it decides, makes decisions and acts on behalf of Kosovo as 'home' and on the other hand, the local has become the 'guest' playing along the rules set by what was initially the 'guest'. In this new set-up, we focus on the local narratives and let them deconstruct the international presence and mission in Kosovo. In doing this, we first 'return' the locals to their original position-that of 'host' - and acknowledge Kosovo as their 'home'. At the same time, we place the missioniser in the position of the 'guest'. In the second step, we deconstruct the 'international narrative' through the stories of the locals and finally let the two deconstruct themselves.

We maintain that this 'reversal' is important, first of all, to transfer focus to local narratives in understanding how Kosovo is conceptualised using Derrida's concept of 'home'. Second, the conflict in Kosovo, along with other developments that led to Yugoslavia's breakup, is largely (and not always rightly) explained as a result of inter-ethnic hatred. This has produced what Edkins has referred to as 'grand narratives' which according to her conceal the fragility of possible 'solutions' (Edkins 2013, 12). Being all-encompassing, the grand narratives are linear and as such they offer an oversimplified 'cause' of the problem in question and ultimately another oversimplified 'solution' to how to deal with it. In her narrative account, Edkins calls for 'troubling' these linear narratives which according to her leave out questions such as trauma, violence, testimony and forgiveness, and how these are perhaps inevitably concealed in searches for causes and solutions:

Searches for solutions assume they know what the 'problem' is and focus on the need to solve it, not to engage with the results or implications of what is happening or has happened. They ignore the way in which it is often difficult even to describe fully or coherently what has in fact happened, let alone subsume it under a label (Edkins 2003, 44).

This article first begins to 'trouble' the linear narrative constructed on Kosovo. In other words, we reverse the pre-established concept of the conflict and argue that, like in any other conflict/war, the events of 1999 in Kosovo were a struggle for domination and power. Paraphrasing Clinton's famous motto: 'No, it's not the old myths and ethnic hatred. It's the political power struggle, stupid' (Žižek and Hamza $2013,38)$. According to the same logic, we go beyond the dichotomous view and look at narratives of other ethnic groups as well. The aim is to renegotiate the way narratives on Kosovo are presented-as an 'either/or' equation between the Serbs and the Albanians and the international actors as the non-aligned, objective actor who seeks to do something in Kosovo beyond petty ethnic politics. Instead, we look at the narratives of the local ethnic groups in Kosovo and the narratives of the international structures in a horizontal scheme and look at them as struggles between stories.

Derrida uses 'home' as a concept when he talks about the notion of hospitality. It refers to 'home' on a personal level-how people welcome each other-but it also 
refers to states as 'home' - how we welcome foreigners, migrants etc. (Derrida, 2000, 104). For Derrida, 'home' is the precondition for hospitality and defines it as 'insofar as it has to do with the ethos, that is, the residence, one's home is the familiar place of dwelling, inasmuch as it is a manner of being there, the manner in which we relate to ourselves and to others, to others as our own or as foreigners' (Derrida $2000,197)$. Bulley goes further in arguing that the unconditional desire for the home, which is impossible to renounce also "should not be renounced", for without the home, "there is no door nor any hospitality" ' (Bulley 2010, 57). The concept of 'home' would not have any meaning without 'host' and 'guest'. A home may not have a 'guest', maybe, but it certainly has a 'host'. Even when we talk about religious sites, we tend to say they are 'homes' of God, in that we attribute them to a subject.

\section{Kosovo's Narratives}

Narrative research is widely used in interpretivist social science. A number of researchers have been using narratives-stories-to give voice to otherwise marginalised discourses and/or groups (Shenhav 2004, 19; Stern, 2005, 166; Selbin 2010, 67; Edkins 2013, 34). Patterson and Monroe (1998, 113) argue that all narratives are essentially normative, no matter how hidden the voice of the narrator. To better contextualise Kosovo's local narratives, it is interesting to look at authors who have engaged with narratives of nations and nationalism and those who have looked at narrative in war/conflicts. Shenhav's interpretivist work on the concept of 'nation' in the discourse of the Israeli Likud party looks at narrative as a 'struggle' the nation has to go through-bloodshed, suffering, mourning, pain (Shenhav 2004, 15). Due to the 'securitisation'1 of Israel, because of the on-going conflict with the Palestinians, Shenhav observes that the speech of narratives 'constructs a collective speaker who addresses the nation with the goal of defending the next generation' (Shenhav 2004, 87).

Our aim is not to identify or proclaim which narratives are dominant or marginal; rather, we approach them as a struggle between stories. Kosovo is a project of a number of 'stakeholders' and as such has a number of narratives. In an immediate categorisation, two groups of narratives are visible: narratives of locals and narratives of internationals. The first, narratives of locals, can be 'named' Kosovo as historical justice, a phrase which in this article denotes the stories of its peoples, ethnic/cultural groups and explains Kosovo as the memory, identity and future of its own population. The second is the Kosovo project or international narrative. This distinction between 'historical justice' and 'project' aims to mark the very different approaches the 'guest' and the 'host' maintain towards Kosovo as 'home'. Kosovo project explains Kosovo as a success story of the interveners, to indicate: 1) the merits of NATO's first attack on a sovereign land as 'humanitarian intervention'; 2) as a success story of conflict management and peace building under the most ambitious UN mission in history (King and Mason 2007, 43); 3) as a triumph of Western democratic values in a post-conflict/post-socialist setting; and 4) as a site of 'European values' and 'best European practices', unfolded via the EU presence in Kosovo and the largest Common Security and Defence Policy (CSDP) mission deployed to date, EULEX. Synthesised, this narrative looks at the Kosovo project as a canvas for the projection 
of Western values (Richmond 2008, 41). Neither of these are compact narratives. On the contrary, they are constantly deconstructed in their inner struggles. In this part of the article, it is essential to note that in terms of 'job description', mandate, aims and performance, there is a clear difference between the different international actors of the Kosovo project (i.e. NATO, the US, the UN, KFOR, EU, EULEX etc.). The interviewees were well acquainted with these differences. However, when talking about themselves (themselves as locals) as subject of intervention and missions, the interviewees see the 'international actors' as homogenous.

What follows below is first a deconstruction of Kosovo's narratives, in which we look at locals as 'host' of their 'home', namely Kosovo. The article takes on board the criticism that Kosovo is too often presented as a battlefield of a dichotomous ethnic conflict and myth-based hatred. As such, it looks at the narratives of all ethnic groups living in Kosovo. Second, using local narratives, we deconstruct the international narrative in which we treat the international missioniser as 'guest'. In both cases, the deconstructed narratives will be synthesised by the author's interpretation.

\section{Kosovo as Historical Justice}

As mentioned previously, when deconstructing the local narratives, we treat Kosovo as the 'home' of its peoples. Elsewhere, we have detailed how the EU mission in Kosovo has altered the notion of 'home', as the concepts of 'guest' and 'host' have been reversed. ${ }^{2}$ The mission, being omnipotent in residing and acting, has turned into 'host' and the local people have become 'guests'. In this article, we re-return 'home' to Kosovo's people and let their 'home' deconstruct itself. Above all, 'home' in the local narratives in this article is also read as a sense of belonging, dignity and respect-not only of having a 'home' as such, but more importantly being the host of it. In returning Kosovo as 'home' to its people we acknowledge Kosovo as their historical justice too. The conceptualisation of historical justice will be deconstructed utilising the works of scholars of nationalism and identity politics, such as Benedict Anderson, Eric Hobsbawm, and Michael Billig.

\section{Albanians: Kosovo Fetish}

In the Albanian narrative, we look at the representation of Kosovo as myth ${ }^{3}$ in our interviews, ${ }^{4}$ anecdotal evidence (Maliqi 2008; Selimi 2008; Heta 2010; Respondent 10 2012, interview, 3 April), literature on Kosovo's national struggle (Kelmendi 1997, 193; Salihu 2005, 42-44; Luci 2008, 92-93; Maliqi 2010, 53) and media discourse (television and news portals). ${ }^{5}$ This is not an attempt to claim a linear narrative of Kosovo Albanians. Different interest groups may have diverse interests, values and identities, which in turn diversifies narratives. Nor is it an attempt to look at 'nation' and 'ethnic group' as homogenous and static categories. Needless to say, these concepts are always contested and dynamic. Yet, the literature on nationalism and evidence from field work reveals that when it comes to the paradigmatic issue-which for societies in the making is the foundation of a state-there is an overarching consensus on statehood. In this case, there is an overarching consensus of Kosovo's statehood-Kosovo as 'home'. Looking more at the historical past, we 
develop a bias/assumption that 'independence' has framed Kosovo's history for the past hundred years and to a large extent continues to frame its present as well. In this narrative, Kosovo is the historical justice of people who have lived in inhumane conditions as an ethnic group in the Yugoslav federation, while simultaneously the latter was going through changes of democratic evolution and economic development, with the paradoxes of democratic evolution and economic development. It is the Kosovo entrenched in the national (imagined) memory and a dreamlike project for making it an independent state. In this narrative Kosovo is both somewhat religion and identity.

Kosovo's (remembered) organised struggle for self-determination may be traced back to 1878 along with other nation-state movements in the region at the start of the fall of Ottoman Empire (Anderson 2006, 84). ${ }^{6}$ It had never been a 'state' in its own right, but has always been part of something bigger (the Ottoman Empire, Yugoslavia etc.). It has never been a 'home', rather a part (room, corridor, back yard) of bigger homes, or mansions. For a long time, the issue of 'independence' and 'statehood' (building a 'home') in Kosovo has been a project of different segments of society which do not necessarily share an ideological, political and cultural identity. The project of building a 'home', and more importantly being the 'host' of it, has had as its promoter the pacifists of Kosovo's Democratic League (KDL), who refused to resort to violence against Serbian troops, maintaining that a Gandhi-like ideology of resistance and pacifism was the only way through. Yet Kosovo as 'home' has also been a project of the guerrilla movement, the Kosovo Liberation Army (KLA) - the insurgent against the Serbian army in 1999. The collective memory and the current struggle of the nation consider independence as something sacred: sacred to religious levels characterised by devotion, adoration and, most importantly, sacrifice. Hobsbawm argues that nationalism is a civic religion that replaces religion, 'because of the near pathological character of nationalism, nations, inspire love, and often profoundly self-sacrifice' (Hobsbawm 2012, 66). In a similar vein, Anderson reminds us that while historians, diplomats, politicians and social scientists are quite at ease with the idea of 'national interest', for most ordinary people of whatever class the whole point of the nation is that it is interestless. Just for that reason, it can ask for sacrifices (Anderson 2006, 70).

Kosovo thus represents this 'home' that has never been, has never materialised, but has been dreamt of and fought for. As such it has always been idealised. In Spectres of Marx, Derrida writes that as soon as there is production, there is fetishism, idealisation, autonomisation and automatisation, dematerialisation and spectral incorporation. He adds further that this turns concepts into religion (Derrida 2006, 164-166). The collective memory views an 'independent Kosovo' as a perennial cause; it repeats it throughout the imagined historical events and struggles and idealises it as sublime, turning it ultimately into a fetish. It becomes a mirage, and at the same time loses its intrinsic meaning. It is not thought of simply as a 'home' to live in and be able to own materially. Rather, it is an ideal, a reparation and above all, justice. After decades of living in 'abnormal' conditions (politically, economically, socially and psychologically), the very sense of what Kosovo as 'home'/state represented for the people lost a number of layers that a 'normal' state has for its own citizens (i.e. taxation, education, pensions, etc.). In time, Kosovo had been downgraded into this ideology inseminating resistance, pride, sacrifice and a sense 
of collectivity. Most people who saw Kosovo 'liberated' in 1999, had a vague or no memory of a normally functioning state apparatus. The 'state' (Serbia/Yugoslavia) was the enemy and the structure to be feared, resisted and escaped from. The 'state' (Kosovo) they were asking for was a restoration of their lost possibility of having a 'home' and being acknowledged as 'hosts'. The fetishism of what the 'state' is still lingers in daily political life after all these years. In the account of their experience in Kosovo, two UN Interim Administration Mission in Kosovo (UNMIK) officials wrote that 'after so many years of life and death, struggling, survival and sacrifice, the Kosovar voter was not used to ask from the elected politicians to deal with day-to-day issues like irrigation or waste management' (King and Mason 2007, 132-138). On a similar note, a senior Kosovar journalist argues that 'it is difficult to make that shift now ... to think of a state as a state that is there to simplify and regulate your life. It is in our subconscious that we don't deserve liberty as humans but we have it because something supernatural has happened' (Respondent 32012 , interview, 26 November).

Fetishised, Kosovo becomes the political and social identity of the Albanians. Campbell defines identity as difference, saying that there are no pre-existing foundations that determine an identity; instead they are constructed through the differences between inside and outside (Campbell 1998b, 5). Apart from the need to identify with an independent state as 'home', Kosovo is an identity in opposition to the other; in opposition to Serbia and the Serbs, not only as perpetrators but also in the obstruction that Serbia makes to the very idea of having an independent Kosovo. In Minding the Gap: The Subject of Politics, Laclau and Zac (1994, 31-34) argue that people underscore a generally felt need to belong to society, because it is this sense of belonging that establishes our identity and allows for agency. In societies that are 'unfinished' in establishing their 'home', the sense of belonging and identifying with one's country is even higher. For instance, toponyms such as 'Kurdistan', 'Catalonia' or 'Quebec' become a common vernacular in the identity of the respective groups. Throughout the Yugoslav period, for instance, ordinary people from Kosovo would refuse to say 'I come from Yugoslavia', notwithstanding that it would not arbitrarily imply any sort of ethnic attribution. The vast majority would have preferred to respond 'I am from Kosovo', as to denote the fact that they did not see themselves as part of the political state they lived in. Rather, they saw themselves and hence wanted to be acknowledged as people, 'hosts', of this imagined 'home'. Currently, it is rather common to see Kosovars at conferences or international meetings stating that 'I come from the Republic of Kosovo'. This, however, should not be seen as a mere identification with a 'republic' in a material way. 'Kosova Republikë' (Republic of Kosovo) was a common illegal graffiti slogan in the late 1970 s and throughout the 1980s, when Kosovo's autonomy had been revoked and it implies on-going struggle. Nowadays, because it is 'unfinished', Kosovo is not a 'home' yet. As such, it is claimed by Kosovo Albanians as a historical right after the catharsis; as a remedy for every right they feel was taken away from them, and for all the injustices they perceive themselves to have lived through.

\section{The Serbs: Kosovo and the Injustice of International Aggression}

In the Serbian discourse, the events of 1999 are not known as a war between Serbia's government and the Albanian majority. In the interviews with Serbian 
respondents (Respondent 5 2012, interview, 23 November; Respondent 62013 , interview, 16 October; Respondent 2 2013, interview, 16 October), in the Serbian media (Beta 2011) and Serbian school books (Nikolic 2005, 109; Djuric 2007, 37), the events of 1999 are referred to as 'NATO aggression', which was then followed by the internationalisation of Kosovo's case. The removal of Serbian forces from Kosovo and the installation of international structures is also seen as a Western project for creating an Albanian Kosovo while belittling the Serbs. This in turn defines the historical injustice.

In this narrative Kosovo, is also unfinished in the 'home' and identity status. Whose 'home' is it now that it is not part of Serbia anymore? What is its identity, and more importantly how does the new situation affect the identity of local Serbs? These questions are not merely rhetorical, considering how porous the concept of 'home' is in the case of Kosovo. For instance, since the end of the war, Kosovo Serbs have been living in three different political entities/contexts/'homes' at the same time, depending on in which area they were located. Therefore, the Serbs in south-east Kosovo were living under the 'Albanian system' and later in 'independent' Kosovo; the Serbs in the south and Gracanica have been living in 'Kosovo under UNSC $1244^{\prime} .{ }^{7}$ The Serbs in the north (North Mitrovica, Zubin Potok, Leposavic and Zvecan) have been living in 'Serbia'. Because there has not been a uniform legal system of governing and the 'borders' (political and administrative) were porous, one could basically 'choose' under which authority to live. The narratives of the Serbs should be viewed in this shifting context.

The city of Mitrovica-divided at the bridge over the Ibar River between an Albanian part in the south and a Serbian part in the north-marks the 'border' between the four ethnically Serbian municipalities and the rest of Kosovo. Derrida argues that boundary (as in border) defines the line where one thing ends and another begins, and as much as it is about identification, it is about exclusion (Derrida 2003b, 72). For Derrida, reflecting critically on the nature of limits and boundaries transforms our well-established way of thinking about identity as a homogenous and self-enclosed totality. He makes a distinction between what the Swiss-Italian border in Mont Blanc means in terms of division and what the Berlin Wall as a border meant. Since 1999, Serbian municipalities in the north have been outside of the international/local jurisdiction and control. Showing their opposition to Kosovo's partitioning from Serbia, they have protested and resisted new establishments while maintaining ties with Serbia instead. For around 15 years now, the 'border' has become more solid, which for Kosovo Albanians has been the greatest and most dangerous failure of the international community, particularly UNMIK and EULEX. For UNMIK, any intervention to include the north in 'Kosovo's' jurisdiction was off the table because it would have incited violence from the Serbs and would have jeopardised the 'stability' achieved in Kosovo (Respondent 82013 , interview, 4 April) EULEX, on the other hand, cannot take action because they 'lack the capabilities to do so and most importantly because any move to do so would imply that EULEX is supporting Kosovo's independence and that would outrage the Serbs' (Respondent 1 2012, interview, 10 October).

The 'border' at the bridge does not only mark the division of Albanians and Serbs and even Serbs and the 'others' of Kosovo. Until 2013, the 'border' marked the 
end of the international structures (police, courts, military, etc.), making the 'northern' part of Kosovo a grey zone-a fault line between Serbia and Kosovo. When passing the 'border' at Mitrovica's bridge, one also transcends 'Kosovo' and finds oneself in Serbia. The cars carry Serbian number plates (if they carry any), mobile phones receive the message 'Welcome to Serbia' and one is automatically connected to Serbian phone companies. Schools, institutions and the like have the labels of Serbian ministries and institutions. In supermarkets one can only purchase goods 'Made in Serbia' and everything is paid in 'dinar'—Serbia's currency. ${ }^{8}$

'North' is least of all a geographical notion. When passing the 'border'/bridge, one also travels in time. The city's scenery goes back to the socialist/Yugoslav setting of the 1990s. A state of emergency and 'securitisation' is immediately felt as there are no signs of police or any security structure, and EU officials patrol in bulletproof cars and vests. Banal nationalism is omnipresent, with 'patriotic' slogans and Serbian flags found everywhere (Billig 1995, 37). While in a silent war with the Albanian majority, the Serbs in the north are fierce opponents of the international presence too. They see the US and the EU/EULEX-but not so much the UN-as structures which are there to make Kosovo an independent state in which the Serbs are side-lined by the Albanian majority. In the north, the feeling of being abandoned/betrayed by Serbia itself has increased, since negotiations started between Belgrade and Pristina. ${ }^{9}$ Posters of Serbia's and Kosovo's prime ministers shaking hands in EU High Representative Catherine Ashton's office are omnipresent in the city, accompanied by the caption 'We will never forget'. 'For 15 years, I protest here against the Pristina's secessionism. And now what? Dacic goes to Brussels and kisses with Thaçi and Ashton', argues a local taxi driver in North Mitrovica (Respondent 2 2013, interview, 16 October $)^{10}$

For Serbs in Gracanica and those in other parts of Kosovo, the situation is slightly different. Although they retain the dissatisfaction with the fact that Kosovo is in the process of (eventually) becoming a fully-fledged independent state-an Albanianhosted 'home' - most of them are already part of Kosovo's institutions and structures and/or they work with the international structures and organisations in Kosovo. They feel that the post-1999 period is all about the Albanians, but because Kosovo has to appear 'multi-ethnic' and 'tolerant' abroad, the international structures want to keep the Serbs to make that point. 'We (the Serbs) are merely a decoration here. Brussels and Washington need us here so that they can say that Kosovo is the country of everyone. And we all know that is not true. Least of all it is of the Serbs. And it's not of the Albanians either. The West lures the Albanians with power just to make its agenda happen', argues a local Serb in Gračanica working with NGOs (Respondent 5 2012, interview, 23 November). He explains that Kosovo Serbs are not on the agenda of any of the 'stakeholders' who have power over Kosovo. 'The EU is negotiating with Dačić and Thaçi on Kosovo's future, but our interests-interests of Kosovo Serbs-are not represented. Serbia is trying to buy its own way to the EU; Kosovo is buying its independence and the EU is showing that they deserved the Nobel Prize' (Respondent 5 2012, interview, 23 November). 


\section{Multi-ethnic Kosovo: The Insignificant 'Others'}

The literature on Kosovo and developments of the late 1990s is entrenched in explaining the developments as a story of two characters (the Albanians and the Serbs) and one single topic-the Balkan, tribal-like eruption of violence, rooted in myths and a historical past. Other minorities (ethnic, religious, cultural, etc.) hardly trigger even a marginal debate. This approach has not only further mystified the whole debate of what exactly happened during the war but it has also influenced policy choices on how to deal with it. When engaging with deconstruction, Derrida takes what is marginal and makes it central to the debate and discussion. A similar reading can be given to the question of the 'visibility' of 'other' ethnic minorities. If they are marginalised in the picture and are treated as a liminal anomaly, we must at least ask why. We maintain that what happened during and after the war is a struggle for power and a fight for survival, accommodation, dominance and power of all Kosovo's major and marginal groups: Albanians, Serbs, Roma, Bosniaks, Turks, Croats, Ashkali, etc. Being smaller in number or structurally detached from high politics, these minorities have remained outside of the dichotomous debate, the Albanians or the Serbs. In the political discourse of the international community, minority politics, human rights, or even the whole concept of cultural heritage have been downgraded as 'rights' to accommodate the Serbian minority in the new settlement. The Ahtisaari Plan is entirely based on the logic of granting asymmetrical power to the Serbs (United Nations Security Council 2007, 3-18). The values of 'communities' and minorities appear to be not that important when it comes to other, non-Serb minorities. Looking at media reports and documentaries on other minorities in Kosovo, it is clear that the focus on 'politically more important' minorities is not present only in legislation.

The Roma, for instance, who in the eyes of the Albanians are seen as collaborators of the Serbs during the war, are 'shifted' into the domain of the Serbs. ${ }^{11}$ As far as the international project is concerned, the discourse about the need to accommodate the Serbs does not apply to the Roma. Throughout the period 1999-2010, Roma were internally displaced by UNMIK to what was to be a temporary camp near Plemetin. For ten years, human rights organisations have highlighted how this camp is located near industrial zones, and contaminated with lead and other forms of toxic waste (Life in Kosovo Show 2009). Medical evidence has shown that most Roma children born in the camp carry toxic substances in their blood. In this case, the inhumane conditions of Roma were not hampering the 'multi-ethnic' image of Kosovo as much as was, for instance, the inability of Serbs and Albanians to sell their home-grown vegetables at a joint market. After all, the Roma scandal was a violation of human rights principles (strictly speaking) but it did not constitute a violation of 'community rights', 'opportunities for the communities' or the 'multi-ethnic' image of Kosovo. This not only displays the utterly discriminatory logic of attribution but most of all it detaches the concept of minority rights from the basic human rights concept, ultimately displaying the pervertibility of 'multi-ethnicity'.

Rrahmon Stollaku, a local Roma from Fushë-Kosova, who was initially employed at the Ministry for Communities and the Return, explains how the issues of Roma, Ashkali and Egyptians are simply not seen as part of the problem/solution. 'There 
is a $10 \%$ quota for employing non-Albanian communities in public institutions. But it has been obvious throughout all these years that the Serbian group is always favoured, for political reasons. I mean (and you know it too), nobody will be shocked if there is an open discrimination towards a Roma, but if that happens against a Serb, all international media will be alarmed' (Life in Kosovo Show 2012). Gadime is a town where the Ashkali community is quite large in number. Shpejtim Limani, a local from this town argues that although the Ashkali minority is the second-largest group (after the Albanians), the Serbs are given priority in employment and education (Life in Kosovo Show 2012).

Kosovo's Turks did not openly 'favour' any particular side during the war, but were nonetheless seen as allies of the Albanians. Concentrated largely in Prizren and eastern Kosovo, they were more organised to benefit in the post-war period with the Albanians in power. They have developed further ties with Turkey and profited from decentralisation extending their cultural and linguistic rights. As with other ethnic minorities, a quota is set for their representation in public institutions, although this in no way represents their accommodation in society at large. Bosniaks and Croats have a rather hybrid post-war identification. While during the war they were seen as opponents of the Serbs due to the previous wars in their mother states, they were not as well accommodated in the aftermath, due to linguistic and cultural proximity to the Serbs. ${ }^{12}$ Along with the Roma, they remain not only on the margins of the Serbo-Albanian struggle but also of the international project.

We term these groups the insignificant 'others' because we witness the autoimmunity of multi-ethnicity, in which it tries to exist by consciously marginalising 'others'. In the case of Roma, Turks, Bosniaks and Ashkali, Kosovo somehow tries to become multi-ethnic by side-lining them. It is multi-ethnic while the discourse mentions the Serbians as a marked category; the rest are simply 'others'. They are insignificant not only by being marginalised in the discourse but above all by being a group of 'others', with no name or agency. Therefore, it becomes imperative to ask how a minority group or, in the EU's language 'a community' is defined. Or maybe the question should be asked, who and for whom the picture of Kosovo as a home of 'all communities' is important? The concept of 'multi-ethnicity' and 'home of all communities' implies importance, relevance and equality. Yet certain groups appear to be more important and more relevant for the multi-ethnic picture. Or as Orwell put it, some animals are more equal than others.

\section{Kosovo Project: From UNMIKISTAN to EULEKSPERIMENT}

As we have returned Kosovo as 'home' to its people/'host', we have in turn repositioned the missionisers to the 'guest' status. To deconstruct their narrative, aside from our interviews, we will make use of the visual communication modes of the international structures, such as billboards, leaflets, slogans, etc. In looking at them as text, we deconstruct them with the local narratives.

UNMIK's period was characterised by the logic of " "stability" above all' (King and Mason 2007, 65-67). Stability was defined in terms of inter-ethnic relations 
(Musliu 2010, 42-44). Lack of physical violence between Serbs and Albanians marked 'stability' and any physical confrontation between the two was making the situation 'unstable'. All other issues were subordinate to the principle of 'stability'. This was true even in cases where basic democratic principles had to be violated, such as was the case with Prishtina-based newspaper Dita in 2000. After reporting that a suspected Serb, who had been involved in the war against the Albanians, was employed by UNMIK, the head of UNMIK at that time in 2000, Bernard Kouchner, passed a controversial regulation in 'prohibiting media to incite violence' and the newspaper was closed (King and Mason 2007, 107-120). The regulation stated that 'owners, operators, publishers and editors shall refrain from publishing personal details of any person, including name, address or place of work, if the publication of such details would pose a serious threat to the life, safety or security of any such person through vigilante violence or otherwise' (UNMIK/REG/2000/37, 5). Failure to comply with the rules would result in the 'seizure of equipment and/or printed material; and suspension or close down of operations' (UNMIK/REG/2000/37, 6-7). The regulation had further implications in prohibiting other media from engaging with investigative journalism and/or openly criticising the international administration (Hysa 2004, 97-105). Explaining how democracy is autoimmune, Bulley argues that democracy has always had this quasi suicidal possibility with itself-it may commit suicide (impose authoritarian rule and end democracy) to prevent its murder (the democratic end to democracy)' (Bulley 2009, 26). The aim to maintain 'stability' was utterly undemocratic, not only in practice but also in content. Practices like these-where the locals were lectured about democracy while the mission was not adhering to basic democratic principles itself-led to frustration and the coining of the term 'UNMIKISTAN' (King and Mason 2007, 44). The ending 'stan' is Farsi for land, widely used in other Middle-Eastern languages. For instance, 'Afghanistan' means 'the land of the Afghans'. That in turn means that Afghanistan is not the land of anybody else. It is not the land of Algerians, for instance. By the same token, UNMIKISTAN not only denotes Kosovo as 'the land of UNMIK' but at the same time it tells us that this is not 'the land' of somebody else. It appropriates it. UNMIK had an unprecedented and all-encompassing mandate, being in charge of the executive, legislative and judicial functions with which it practically 'appropriated' Kosovo. Locals were using the term to indicate that the mission had turned Kosovo into a corrupt/oligarchic/poor/former Soviet-like republic, where debate, power and decision-making rested in a higher nomenclature, detached from its population.

During the EU mission "multi-ethnicity", "rule of law" and "European values" above all' became omnipresent. UNMIK and EULEX are perceived in a linear fashion in the missions' trajectory in Kosovo. This 'linearity' stretches out also towards the missions' performance. Each of the missions and their structures has tried its best 'models' in promoting democracy in Kosovo. Yet, this has created a sense as of living in a laboratory where local Kosovars are used as units of analysis in the subsequent experimentation process. However, when it comes to EULEX, the criticism is fiercer, firstly because expectations were much higher than what the mission seems to be able to deliver, and secondly, because it was seen as an opportunity to break the 'inefficient' trajectory of UNMIK. For instance, EULEX took on UNMIK's practice of impunity of high-level officials as a commitment for its 
rule-of-law program. However, despite the action taken in dramatic scenes, resembling 'FBI' action flicks, this has remained largely a publicity campaign, as no one in high levels of power was ever judged Kalaja 2012. The high-profile accused were released on grounds of lack of evidence, recalled to court again and released. Actions like these have lowered the popularity of the mission. The frustration of the locals with what they see to be EULEX's inability to live up to its mandate is coined 'EULEKSPERIMENT'-graffiti omnipresent in Prishtina. 'EULEKS' is the Albanian and Serbian pronunciation of EULEX, while the bold ' $\mathrm{KS}$ ' letters are commonly used as a code for 'Kosovo'. Interestingly EULEKSPERIMENT is not only popular amongst the locals. Several EULEX officials have used the term too. 'EULEKSPERIMENT indeed! A lot of what we do in Kosovo is experimental. This is the first mission of the sort and we are trying to find our way. Some of the experiments are successful, others less successful' (Respondent 9 2013, interview, 10 October).

The frustration, however, is not only with the experiment of 'finding' the way to acting strategically, but also with the very way EULEX 'finds' its way to communicate with the locals. While experimenting with the mission, they are also experimenting with locals too, argues a local security studies scholar. 'The recent EULEX advertisements have on their background the theme song of the movie Mission Impossible' (Respondent 4 2012, interview, 21 November). It is rather unclear though, whether fighting corruption is impossible for EULEX itself or whether it is impossible to fight corruption in Kosovo. As part of its communication campaign, EULEX distributed flyers with the sentence 'EULEX has done nothing to fight corruption and serious crime ... More than 200 people and counting', to cynically respond to local criticism. A local legal expert and journalist, argues that on top of everything, EULEX seems to be failing in its own public relations too. 'One cannot brag about procedural acts. You claim "success" on closed cases and verdicts' (Respondent 7 2012, interview, 16 October).

\section{Conclusion: 'Unfinished'}

In this article, we have tried to 'give' Kosovo back as 'home' to its own people and by reinstating their 'host' status we have acknowledged their narrative as a story of their 'home'. Derrida's concept of 'undecidability' —as in the impossibility of attributing something with certainty-is nowhere so organically linked as in the case of Kosovo (Derrida 1992, 24-26). Kosovo as 'home' and its narratives deconstruct themselves ceaselessly and turn it in the exact 'undecidabilitiy'. It is both the point of division and commonality of all narratives. Both international and local narratives are always already both subject and object, yet fully neither at the same time. They exist and are destroyed by their own. Their subjectivity therefore lies in their autoimmunity, which makes them intrinsically undecidable. Their autoimmune subjectivity is inherently undecidable. They themselves are incapable of accepting 'ownership' and this reveals their own instability.

On the one hand, all the narratives claiming Kosovo, see the latter as 'home'. At the same time, it is not fully 'home' of any of the narratives. As such, it cannot be 'home'. The impossibility of identifying Kosovo within narratives also makes it an 'undecidable'. The difficulty lies in identifying it as 'home', and identifying the 
'host(s)' and the 'guest(s)'. Here, Kosovo is a battleground of competing/struggling stories-stories of 'host(s)' and 'guest(s)'. Each of them struggles for supremacy and legitimacy. At the same time, each of them struggles for survival. The Albanian narrative seeks legitimacy as justice after the catharsis, seeks supremacy as the right of the 'victim' and survival to build and own a 'home' (as in a sovereign state). The Serbian narrative seeks legitimacy for the 'home' they have had removed and asserts that they are equally a victim of a broader project of intervention. Narratives of the Roma, Turks and Bosniaks struggle primarily with survival in a dichotomous battleground between the Serbs and the Albanians but also as narratives on their own. Lastly, the international narrative seeks legitimacy in Kosovo as its successful project, a success story of interventions and missions-despite contestation from locals. Every narrative which claims it, 'deserves' it and at the same time each of them is contested, implausible and weak. That is, each of them both 'own' it and at the same time are alien to its 'owning'.

On the other hand, Kosovo is also an arena of shared/common narratives. Bulley comments that 'home is where the ethics are' (Bulley 2010, 46). Along the same lines, Kosovo is 'home' to all narratives that trace in it their stories, histories, memories, values and also ethics. It is a point of commonality primarily for the two dichotomous narratives, seen as binary opposites or mutually exclusive stories. The Serbs and the Albanians have reached a historical point in their claims on Kosovo, where they share Kosovo as a state beyond 'home' (beyond sovereignty). For the Serbs, Kosovo as their previous 'home' is beyond remedy, for the Albanians Kosovo as their new/legitimate 'home' is beyond reach. Thus, it is 'home' of both and none at the same time. It is not present in either way. Above all, all narratives presented in this article share the 'Kosovo to come' - a Kosovo that is not here, not present. Talking about democracy to come, Derrida argues that for democracy remains to come, not only it will remain indefinitely perfectible, hence always insufficient and future, but belonging to the time of the promise' (Derrida 2003a, 89-94). So it is with Kosovo. In all of the narratives, it exists only as a promise. It is a promise to happen in the future. As for now, it is only possible as impossible. Its impossibility is the condition of its possibility. As such, it is defined as the very ideal of Kosovo, by the lack of its presence. It inscribes support or adherence to believe in it. 'I believe in it, I promise, I am in on the promise and in messianic waiting' (Derrida 2003a, 91). Finally, Kosovo as 'home' is hospitable to all narratives, just as much as it is hostile. Derrida explained this as hostipility, to reveal the way hospitality and hostility are both undecidable concepts (Derrida 2002, 356).

What does this mean then for the concept of 'home' and its position towards intervention? What about the concept of mission? Even though the concept of 'home' offers both the possibility to welcome the other and be hospitable, it incites brutal responses towards others in the name of protecting 'home'; it should be defended for the very notion of a desire to have a 'home'. On similar grounds, Derrida has defended the 'home' as 'the unconditional desire, which is impossible to renounce and should not be renounced, for without home, there is no door nor any hospitality' (Derrida 2002, 350-356). Thus, the very existence of it makes the welcoming of the other and more broadly 'hospitality' possible. We do not have to choose or give up options or narratives; rather, we can engage deeper with renegotiating 'home' and ethics as 'home' and intervention as 'ethics'. 


\section{Notes}

1. Securitisation here does not refer to 'securitisation' in the international relations sense, as a concept connected with the Copenhagen School. It is instead used as a term to portray a situation in which a country/society still considers itself vulnerable, threatened (physically or otherwise) by an external agent, and this in turn leads to a polarisation/heightened inner debate over national interests, national security, remembrance, nationalism, etc.

2. Musliu and Orbie 2014.

3. Considering that 'myth' and 'mythologies' are rather common references in writings on the history and politics of the Balkans, it is important to clarify that myth in this case does not imply anything to do with the 'truthfulness' of stories. Rather, it is more a term to indicate the sacredness of Kosovo.

4. 35 interviews were conducted throughout 2012-2013 in locations around Kosovo.

5. The following online newspapers and portals were analysed: Koha; GazetaExpress; and Telegrafi.

6. The word 'remembered' is used because rather than being an event as such, it describes more a social imaginary, which for Anderson is 'not as a set of ideas; rather it is what enables, through making sense of, the practices of society ... and it presents the ways in which people imagine their social existence, how they fit together with others, how things go on between them and their fellows, the expectations that are normally met, and the deeper normative notions and images that underlie these expectations'.

7. Kosovo's official denomination while under UNMIK.

8. Kosovo has used the euro as its currency since January 2002.

9. The article makes use of 'Pristina' as an internationally recognized name for the city. In Albanian the city is written as 'Pristina', whereas in Serbian 'Pristina'. The choice made on the article does not hold an ethnic bias.

10. Kosovo's PM, Hashim Thaçi, former leader of the KLA, has been on Serbia's black list for almost 20 years. Serbia's PM, Ivica Dacic was the spokesperson of Slobodan Milosevic in 1992.

11. Along with the Serbian population, 50,000 Roma fled Albanian-inhabited cities after the war.

12. It is essential to mention that in the first years after the war, speaking in Serbian/Bosnian/Croatian was as dangerous as being an Albanian during the war. Valentin Krumov, a Bulgarian UN official was shot in Prishtina in 1999 because he had spoken Serbian. The aftermath of the war was a state of emergency for people seeking revenge. Prishtina was going through a socio-urban challenge with a massive migration of families from different cities and/or areas. For many people, the first and only contact with hearing Serbian was the war experience.

\section{Bibliography}

Anderson, B. (2006) Imagined Communities (London: Verso).

Kouchner, B. [Special Representative of the Secretary General of the United Nations Mission in Kosovo] (2000) On the Conduct of the Print Media in Kosovo, UNMIK Regulation No. 2000/37. Prishtina. Available online at: http://www.unmikonline.org/regulations/2000/reg37-00.htm.

Beta (2011) 'SRS: Agresija NATO-a na severu KiM', Beta (radio program B92).

Billig, M. (1995) Banal Nationalism (London: Sage).

Bulley, D. (2009) Ethics as Foreign Policy. Britain, the EU and the Other (New York: Routledge).

Bulley, D. (2010) 'Home is where the human is? Ethics, intervention and hospitality in Kosovo', Millennium, 39:1, 43-63.

Campbell, D. (1998a) 'MetaBosnia: Narratives of Bosnian war', Journal of International Studies, 24, 261281.

Campbell, D. (1998b) National Deconstruction. Violence, Identity, and Justice in Bosnia (Minneapolis, MN: University of Minnesota Press).

Derrida, J. (1992) 'Force of law', trans. M. Quintance, in D. Cornell, M. Rosenfeld and D. G. Carlson (eds), Deconstruction and the Possibility of Justice (London: Routledge), 3-67.

Derrida, J. (2000) Of Hospitality (Stanford, CA: Stanford University Press).

Derrida, J. (2002) 'Hostipitality', in G. Anidjar (ed.), Acts of Religion (London: Routledge), 356-420. 
Derrida, J. (2003a) 'Autoimmunity: Real and symbolic suicides', in G. Borradori (ed.), Philosophy in A Time of Terror (Chicago, IL: Chicago University Press), 85-136.

Derrida, J. (2003b) Rouges (Stanford, CA: Stanford University Press).

Derrida, J. (2006) Specters of Marx: The State of the Debt, the Work of Mourning ot the New International (London: Routledge).

Djuric, V. (2007) Geografija (Beograd: Zavoda za udzbenike).

Edkins, J. (2003) Trauma and the Memory of Politics (Cambridge: Cambridge University Press).

Edkins, J. (2013) 'Novel writing in international relations: Openings for a creative practice', Security Dialogue, 44:4, 281-297.

Heta, A. (2010) 'Politics of contemporary art', in A. Heta and V. Osmani (eds), Are You a Tourist or a Traveller? (Prishtina: Stacion Centre for Contemporary Art).

Hobsbawm, E. (2012) How to Change the World: Reflections on Marx and Marixsm (New Haven, CT: Yale University Press).

Hysa, Y. (2004) 'Kosovo a permanent protectorate', in E. Newman and R. Rich (eds), The UN Role in Promoting Democracy: Between Ideals and Reality (New York: United Nations University Press), ch. 12.

Kalaja, B. (2012) 'The war against corruption through media spectacles', Preportr, 15 October.

Kelmendi, M. (1997) P'ej shpie Na Dutz Na Ho UTZ Toward Home (Prishtina: Gani Bobi).

King, I. and Mason, W. (2007) Peace at Any Price (Prishtina: Koha Print).

Laclau, E. and Zac, L. (1994) 'Minding the gap: The subject of politics', in E. Laclau (ed.), The Making of Political Identities (London: Verso), 11-39.

Life in Kosovo Show (2009) Life in Camps. Radio Television of Kosovo, Prishtina. Video (26.50 minutes).

Life in Kosovo Show (2012) Employment of Roma, Ashkali and Egyptians in Kosovo. Radio Television of Kosovo, Prishtina, 17 December, Video (24:50 minutes).

Luci, N. (2008) 'Superfluity: Kosovo', in A. Hummer, B. Buden and A. Heta (eds), Cultural Policies or Crisis Management? (Prishtina: Stacion Centre for Contemporary Art).

Maliqi, S. (2008) 'Cultural Policies as Crisis Management', in A. Hummer, B. Buden and A. Heta (eds), Cultural Policies or Crisis Management? (Prishtina: Stacion Centre for Contemporary Art).

Maliqi, S. (2010) Nyja e Kosoves (Prishtina: Gani Bobi).

Musliu, V. (2010) Challenges for the EU Mission in Kosovo: Economic Development and/or Democracy Promotion (Catholic University of Leuven, Masters thesis, unpublished).

Musliu, V. and Orbie, J. (2014) 'Deconstructing the EU mission in Kosovo: What's in a name?', European Foreign Affairs Review, 19:3, 411-428.

Nikolic, D. K. (2005) Uporedna pravna istorija. (Niš: Sven).

Patterson, M. and Monroe, M. R. (1998) 'Narrative in political science', Annual review of Political Science, 1, 315-331.

Respondent 1. (2012) pers.comm., November 27.

Respondent 2. (2013) pers.comm., April 4.

Respondent 3. (2012) pers. comm., 26 November.

Respondent 4. (2012) pers.comm., November 21.

Respondent 5. (2012) pers.comm., October 16.

Respondent 6. (2013) pers. comm., November 23.

Respondent 7. (2012) pers.comm., October 16.

Respondent 8. (2013) pers.comm., April 4.

Respondent 9. (2013) pers. comm., October 10.

Respondent 10. (2012) pers. comm., 3 April.

Richmond, O. (2008) 'Welfare and the civil peace-poverty with rights?', in M. Pugh, N. Cooper and M. Turner (eds), Whose Peace? Critical Perspectives on the Political Economy of Peacebuilding (Basingstoke: Palgrave MacMillan).

Salihu, A. (2005) The Interpreted Postmodern for the Albanians (Prishtina: Gani Bobi).

Selbin, E. (2010) Revolution, Rebellion, Resistance: The Power of Story (London: Zed). 
Selimi, P. (2008) 'Cultural policies as crisis management', in A. Hummer, B. Buden and A. Heta (eds), Cultural Policies or Conflict Management (Prishtina: Stacion Centre for Contemporary Art).

Shenhav, S. (2004) 'Once upon a time there was a nation: Narrative conceptualization analysis, the concept of "nation" in the discourse of Israeli Likud party leaders', Discourse $\theta$ Society, 15:1, 81-104.

Stern, M. (2005) Naming Security-Constructing Identity: 'Mayan Women' in Guatemala on the Eve of 'Peace' (Manchester: Manchester University Press).

United Nations Security Council (2007) Comprehensive Proposal for the Kosovo Status Settlement (New York: The Security Council).

Žižek, S. and Hamza, A. (2013) From Myth to Symptom: the Case of Kosovo (Prishtina: Kolektivi Mazterializmi Diaelektik).

\section{About the Authors}

Vjosa Musliu is a postdoctoral researcher at the Centre for EU Studies in Ghent University, Belgium, email: vjosa.musliu@ugent.be

Jan Orbie is a professor at the Department of Political Science and Director of the Centre for EU Studies, email: Jan.Orbie@ugent.be 